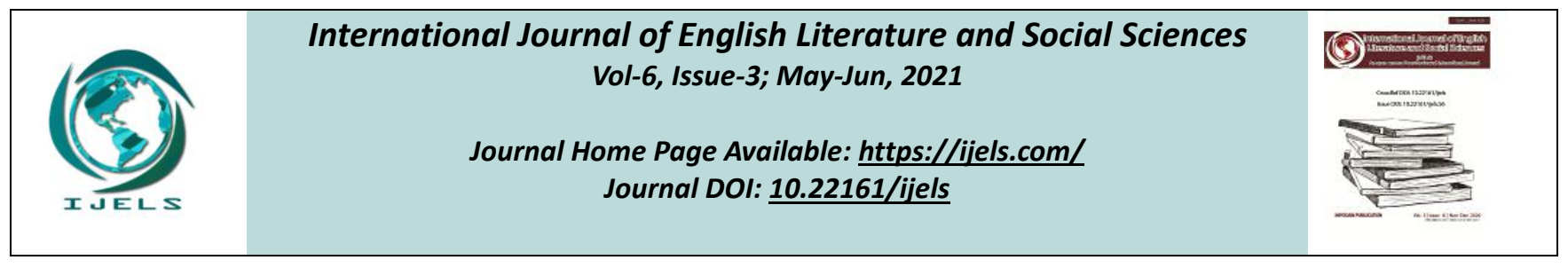

Peer-Reviewed Journal

\title{
Comparative Study of Stress among Students of different Streams Science and Arts
}

\author{
Shubham Sharma ${ }^{1}$, Dr. B.P. Chamola ${ }^{2}$, Nikita Pandey ${ }^{3}$ \\ ${ }^{1,3}$ Department of psychology, Doon University, Dehradun, India \\ ${ }^{2}$ Department of mathematics, Jaypee Institute of Information Technology, Noida, India
}

Received: 30 Mar 2021; Received in revised form: 09 May 2021; Accepted: 29 May 2021; Available online: 14 May 2021

(C2021 The Author(s). Published by Infogain Publication. This is an open access article under the CC BY license

(https://creativecommons.org/licenses/by/4.0/).

\begin{abstract}
In today's dynamic world, there's a huge shift in our philosophies, knowledge and our scheme. With acculturation creating a powerful impact on Indian society, the present Indian society may be a hybrid version of uniting of its authentic attributes and its Western counterparts' characteristics. The shift in social structure alongside advancement in technology features a nice influence on our life, our holistic well-being. The study aims at establishing the stress level in Indian adolescents pursuing various academic courses, namely science and arts. The sample size of the research was 120, where 60 were from science stream and 60 were from arts. These 60 students in each stream were further bifurcated into 30 males and 30 females. The stress levels of the students were calculated using Stress questionnaire by Mohammad Aziz Shah Mohamed Arip. The students were asked to fill the questionnaire as honestly as possible after they were asked to sign a consent form. Thereafter, the data was utilized in calculating the t-test using SPSS. The findings of the research suggest that there is a significance difference in the stress level of students pursuing arts and students pursuing science. The study aims at establishing findings that would help manage the stress levels of the students that has been on increase and also curb it in order to increase the efficiency and working of the students; resulting in the growth and development of the society.
\end{abstract}

Keywords-Academic Stress, Science, Arts, Senior Secondary Students.

\section{REVIEW OF LITERATURE}

Various research articles in the relevant topic have been reviewed. Across various countries, cultures and ethnic groups academic stress has been identified as an unfavorable issue (Wong, Wong \& Scott 2006).

In India studies connect the academic stress as negative consequences [Rangaswami (1982)and Verma, Sharma \& Harson (2002)]. In India students of rural area are vulnerable to depression, anxiety and stress as it has been found on study on depression, anxiety and stress among science, commerce and arts in a junior college of students of rural area (Baviskar et al. (2013)].

It has been found that students of Arts had higher level of depression as compared to their companion from science and commerce streams. Students who were in $12^{\text {th }}$ class seems more stressful as they have to face board ex- ams. Regarding correlation between parental expectations and stress among adolescents, it was observed that few studies were carried out in India. Comparably none of the studies were carried out in the Assam and in the north eastern region.

Due to high level of stress in students' academia were seen to exhibit signs of depression, anxiety, school refusals, increased irritability, complaints and phobia which reduced their interest in school work. This leads to decreased in concentration and reduced memory functioning, subsequently, poor academic performance (Chan et al.1999).

According to Krishna Lal (2013)the students today are facing with new challenges in education calling for greater effort from students. Kaur (2014)accredited that mental health of teenagers get affected due to the academic 
stress. Girls were found poor mental health as compared to the boys in reference to academic stress. This was accounted on the study that pressure from parents and strain on students that leads to worsen mental health.

Dhull and Kumari (2015) conducted a study on "Academic stress among adolescents in relation to gender". From their finding it is indicated that, there is significant difference between academic stress of male and female adolescents. Female subjects were experienced to be under more academic stress as compared to their male fellow.

According to Ghosh (2016) students in private schools have more academic stress than their equivalent in government schools. Female students found higher academic stress than male students.

Prabhu (2015) researched on various social, financial, environmental factors that affect level of stress. In this study on the higher secondary students, it was implied that male students are more stressed than the female students. Urban student's academic stress is greater than the rural students. Private student's stress is higher than the Govt. school student's stress. Students from Arts students are less stressed than the students from Science stream.

Dimitrov (2017)in his study claimed that stressed can be inscribed by assured that the students give highest importance to their welfare. He also concluded that the education system is more to do with the academic qualifications and does not contribute enough to the holistic development of students.

Subramani and Kadhiravan (2017) disclosed the link between academic stress and mental health among students. They inscribed that academic stress and mental health are correlated and that students are confined with the academic structure. They also hypothesized that students from private schools are more pressurized as compared to students from government schools due to the excess of homework and other academic related assignments.

Reddy (2018)in his study concludes that stream wise difference in stress exists in students. Correlational Studies conducted on academic performance and academic stress show a clear negative correlation between the variables.

A 2012 Lancet report quoted that the 15-29 age group in India have the highest rate of suicide in the world (as cited in "India has the Highest Suicide Rate"). The National Crime Record Bureau (2014) registered that $1.8 \%$ of students committed suicide due to failing in examinations. There was an $80 \%$ rise in suicide rate due to academic stress in a city in India during a one- year time frame as published by the bureau (2014) .There is one student every hour that commits suicide, according to the statistics pub- lish to adapt to a new conditioned by National Crime Records Bureau. (Saha, 2017). It becomes very important to deal with stress at all levels, whether it is personal or social or professional level.

Stress may result in varied effects on an individual. Stress effects can commence on different levels: physiological, psychological and behaviour related. Somatic effects can have myriad medical conditions from ulcers, cardiovascular illness to hormonal issues. Mental results include: anxiety, despondency, burnout, insomnia, dissatisfaction. Behaviour related effects caused by stress can result in meager efficiency in task at hand, overflow of information process, usage of alcohol and other addiction, etc. Excessive usage of these resources may come up with different issues; may affect one's health. We cannot skip the fact that an excessive high or excessive low level of stress characterises our performance in several activities. If there's no strategy adapted so as to scale back stress, its results can increment resulting in real dysfunctionality in the daily chores through tension and struggle.

Considerable evidence shows that stress can cause cardiovascular problems, colitis, and other problems. Although it's arduous to chalk out the role played by stress in our somatic functioning, it becomes more and more obvious that many diseases are caused by stress. Positive and negative aspects are best presented by the relation between stress and performance. On a lower stress level it'd end up that we aren't too engaged to perform at our full capacity. An increased level of stress reduction might improve our performance to a particular point. Probably an optimal level of stress exists in most tasks. Beyond now performance starts to crumble. At a better level of stress we become nervous, troubled in working at our full capacity.

Stress can be laid a negative impact on the body of the person. However, if we focused on its positive side then it becomes motivational for a person to encourage oneself to complete a work on a given period of time. In short, it can be said that it can make a person punctual of time. There are so many remedies such as feedback, yoga, life; skills training, mindfulness, meditation and psychotherapy have been found useful to deal with stress.

\section{Significance of the study}

Though stress is often considered bad but there is always the other side of the coin. The right kind of stress helps in sharpening the mind and reflexes thus helps in boosting memory. "Mild stress" is always needed for efficient and effective working. It can help one to meet daily challenges and can motivate students to reach their goals. The main objective of present study was to compare the academic stress of senior secondary students enrolled in different streams i.e. Science and Arts. 
The present study has taken up for study the one variable i.e., stress. The variable holds significance especially in the population of adolescent. The adolescent is at the stage of life where they feel chock neck competition, parents' pressure and to represent themselves best in the rush. Along with the physical changes, hormonal changes as it is generally occur during the period from puberty to legal adulthood. Hence, an attempt has been made to assess the level of stress among the adolescent will help design appropriate intervention measures to enhance their sense of life. It is believed that school is the second home for the students. So, a large sample of adolescents (students) can be drawn from the schools.

\section{AIMS/OBJECTIVES}

\section{Research Problem}

The present research aim is to study the stress among the students of different streams of senior secondary school in Raiwala, Dehradun (Uttarakhand) India.

\section{Objectives}

1. To find out the difference between academic stress of students enrolled in different streams i.e. science and arts.

2. To find out the difference between academic stress of girls and boys enrolled within the stream i.e. science and arts.

3. To provide suggestive measures to overcome from stress.

\section{Hypothesis}

1. There is no significant difference between academic stress of students enrolled in science and arts stream.

2. There is no significant difference between academic stress of girls and boys enrolled in science and arts stream.

\section{Operational Definition}

Stress: If we talk about in a medical or biological context stress is a physical, mental, or emotional factor that causes bodily or mental tension. Stress can be come from external (i,e., from the environment, psychological, or social situations) or it can be internally (i,e., illness, or from a medical procedure).

Over these years, stress has been associated with many illnesses, ranging from headaches (Gannon et al., 1987) and asthma (Miller and Strunk, 1979), colds (Stone et al., 1987), stomach ulcers (Brady, 1958) and cancer (Jacobs and Charles, 1980). This could be due to: reduced resistance to infection. Research on both humans and animals have shown that stress particularly in the long-term can adversely affect the immune system as corticosteroids suppress its activity and thus increase vulnerability to infection.

\section{Participants:}

The sample is selected to represent the population (adolescents) which we want to study. Since it is difficult to study the entire population, a sample is selected following current procedure. The sample selection process depends on the objectives and the nature of the scale.

In the present study Non probability sampling method will be used. In particularly, purposive sampling method of Non probability sampling method will be used. Sample of those adolescents who are studying in senior secondary of different streams have been chosen. The research will conduct in the neighbourhood schools. A total of sample of 120 students will be taken from neighbourhood schools.

Total 120 participants were selected for the present study out of which, 60 were enrolled in science stream (girls $=30$ and boys $=30$ ), 50 were enrolled in arts stream (girls $=30$ and boys $=30$ )

\section{$\mathrm{N}=12$}

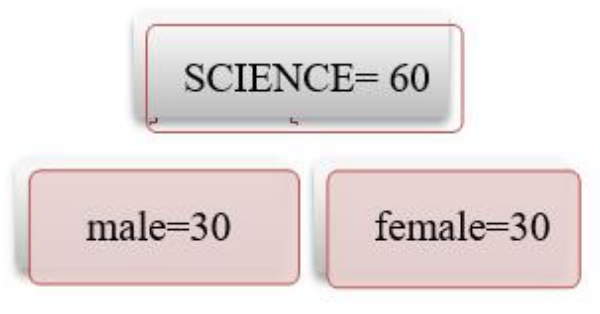

Tools/Techniques:

The following tools will be used to assess stress among the students of different streams.

\section{Stress Questionnaire - Forty Items (Mohammad Aziz Shah Mohamed Arip Dec, 2002):}

The student stress inventory questionnaire is a forty item self - report questionnaire. The respondent has to rate him- 
self/ herself on a 4-point Likert -type scale ranging from 1(Never) to 4(Always). The scale is designed to assess individual differences in the proneness to experience stress in daily life. Higher score on SSI -40 (122-160) signify severe stress, (81-121) moderate stress, (40-80). The reliability of SSI had a high overall reliability coefficient of .857

\section{Demographic Information Sheet:}

Demographic information sheet will be used to collect various demographic information about the sample including 'case number', 'age', 'gender' and 'education'.

\section{Procedure:}

The questionnaire was distributed among the 120 students studying in 8 different neighborhood schools in their class hours and all the required instructions were given to them. It was explained in a friendly atmosphere that the researchers did not intend to test their capabilities and their filling up of questionnaires had nothing to do with school grades. No response is right or wrong. They were also assured that their responses will be kept confidential and only the researcher would have to access their data.

\section{Statistical Techniques}

'Descriptive' and 'inferential statistics' will be used. The data will be analyzed using SPSS software. 'T' test was used to analyze the data.

\section{RESULTS \& DISCUSSION}

Table 1 and Fig. 1 show data on difference of academic stress among students enrolled in science and arts streams. The mean score of academic stress of students enrolled in science stream is 86.9 while that of the students enrolled in arts stream is 80.7 . The obtained t-value $\left(1.913^{* *}\right)$ is found to be significant as compared to the table value (0.042477), so there is statistically significant difference exist between academic stress of students enrolled in science stream and arts stream at $\mathrm{p}=0.05$ level. The result revealed that students enrolled in science stream found academically more stressed as compared to the students enrolled in arts stream hence hypothesis one was rejected.

Table 1: Shows difference between academic stresses of students enrolled in science and arts streams.

\begin{tabular}{|c|c|c|c|l|l|}
\hline Group & N & Mean & SD & 't' value & \multicolumn{1}{|l|}{ Level of significance } \\
\hline Science & 60 & 86.9 & 11.2 & 1.913 & S \\
\cline { 1 - 4 } Arts & 60 & 80.7 & 16.23 & & \\
\hline
\end{tabular}

\section{Significant at $\mathbf{P}=\mathbf{0 . 0 0}$}

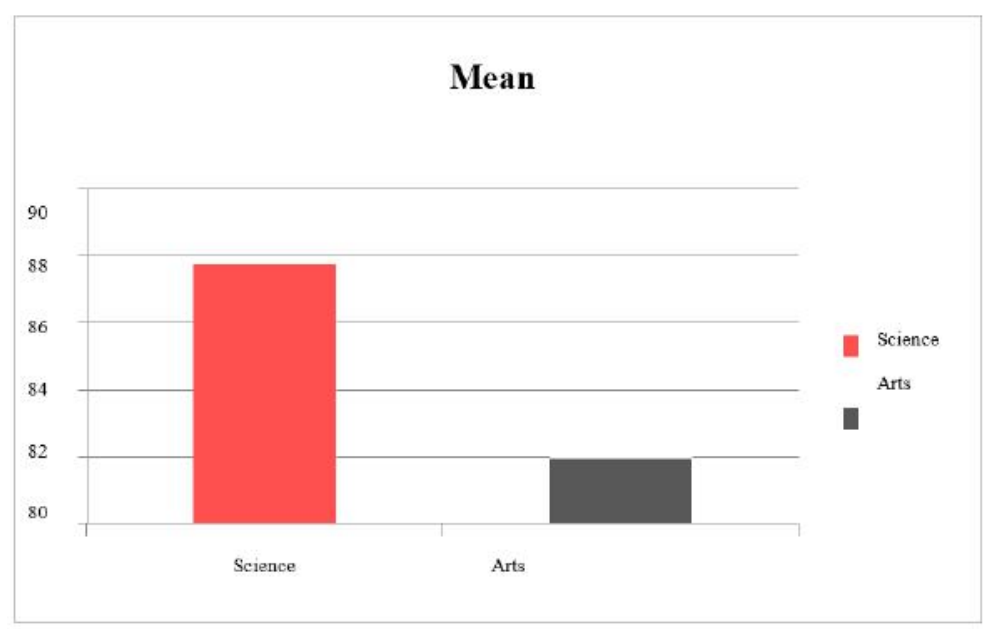

Fig. 1: Shows graphical representation of academic stress mean scores of students enrolled in science and arts streams.

Table 2 and Fig. 2 show dimension wise data of academic stress mean scores of students enrolled in science and arts streams. It is clear from the (Table 2 and fig.2) that students enrolled in science and arts streams vary significantly only on two dimensions out of 4 dimensions namely
'Interpersonal relationship (D-2) $)^{\text {ee }}$ and Environment(D-4)e. It is quite clear that 'Environment' causes more academic stress in students enrolled in science stream and 'Interpersonal relationship' causes more academic stress in students enrolled in arts stream. 
Table 2: Shows dimension wise academic stress mean scores of students enrolled in science and arts streams.

\begin{tabular}{|c|c|c|c|c|c|}
\hline Dimensions & Groups & $\mathbf{M}$ & SD & t- value & Level of significance \\
\hline \multirow[t]{2}{*}{ Physical } & Science & 21.5 & 3.89 & \multirow[t]{2}{*}{6.16319} & \multirow[t]{2}{*}{$S^{* * *}$} \\
\hline & Arts & 17.1 & 5.45 & & \\
\hline \multirow{2}{*}{$\begin{array}{l}\text { Interpersonal relation- } \\
\text { ship }\end{array}$} & Science & 22.32 & 4.07 & \multirow[t]{2}{*}{0.910} & \multirow[t]{2}{*}{ NS } \\
\hline & Arts & 21.03 & 4.83 & & \\
\hline \multirow[t]{2}{*}{ Academic } & Science & 19.05 & 4.02 & \multirow[t]{2}{*}{-3.1642} & \multirow[t]{2}{*}{$\mathbf{S}^{* *}$} \\
\hline & Arts & 21.03 & 5.27 & & \\
\hline \multirow[t]{2}{*}{ Environment } & Science & 25.63 & 2.92 & \multirow[t]{2}{*}{1.54673} & \multirow[t]{2}{*}{ NS } \\
\hline & Arts & 24.95 & 3.28 & & \\
\hline
\end{tabular}

\title{
Dimension wise mean scores
}

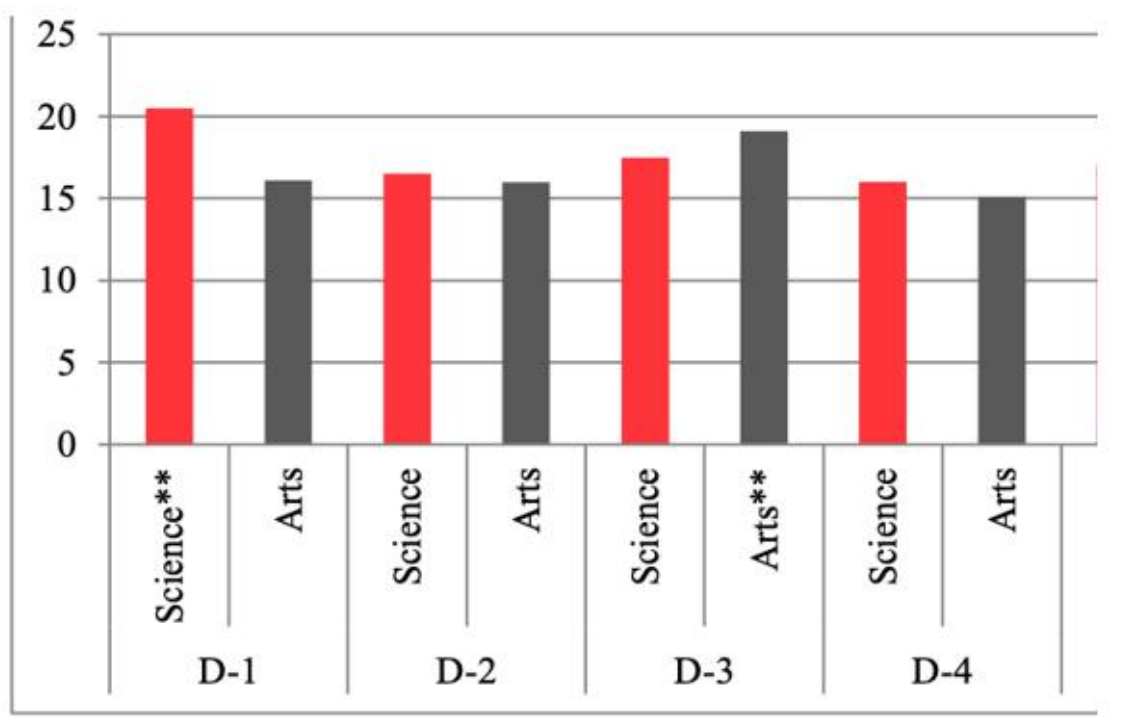

\author{
D-1 Science** \\ D-1 Arts \\ D-2 Science \\ D-2 Arts \\ D-3 Science \\ D-3 Arts** \\ D-4 Science \\ D-4 Arts
}

Fig. 2: Shows graphical representation dimension wise academic stress mean scores of students enrolled in science and arts streams.
Abbreviations:
D-1: Physical
D-2: Interpersonal relationship
D-3: Academic
D-4: Environment

Table 3 and Fig. 3 show data on difference of academic stress among male and female enrolled in science stream. The mean score of academic stress of female en- rolled in science stream is 89 while that of the male enrolled in science stream is 88.48. The obtained t-value $(0.17319)$ is not found to be significant as compared to the 
table value (0.435527), so there is no statistically significant difference exists between academic stress of female and male enrolled in science stream at $\mathrm{p}=0.05$ level. The result revealed that female and male enrolled in science stream didn't vary significantly in their academic stress hence hypothesis second was accepted.

Table 3: Shows difference between academic stresses of girls and boys enrolled in science stream.

\begin{tabular}{|c|c|c|c|c|c|}
\hline Group & $\mathbf{N}$ & Mean & S. D & $\begin{array}{l}\text { 't' } \\
\text { Value }\end{array}$ & Level of significance \\
\hline Female & 30 & 89 & 12.16 & \multirow[t]{2}{*}{0.17319} & \multirow[t]{2}{*}{ NS } \\
\hline Male & 30 & 88.48 & 10.28 & & \\
\hline
\end{tabular}

\section{Not significant at $P=0.05$}

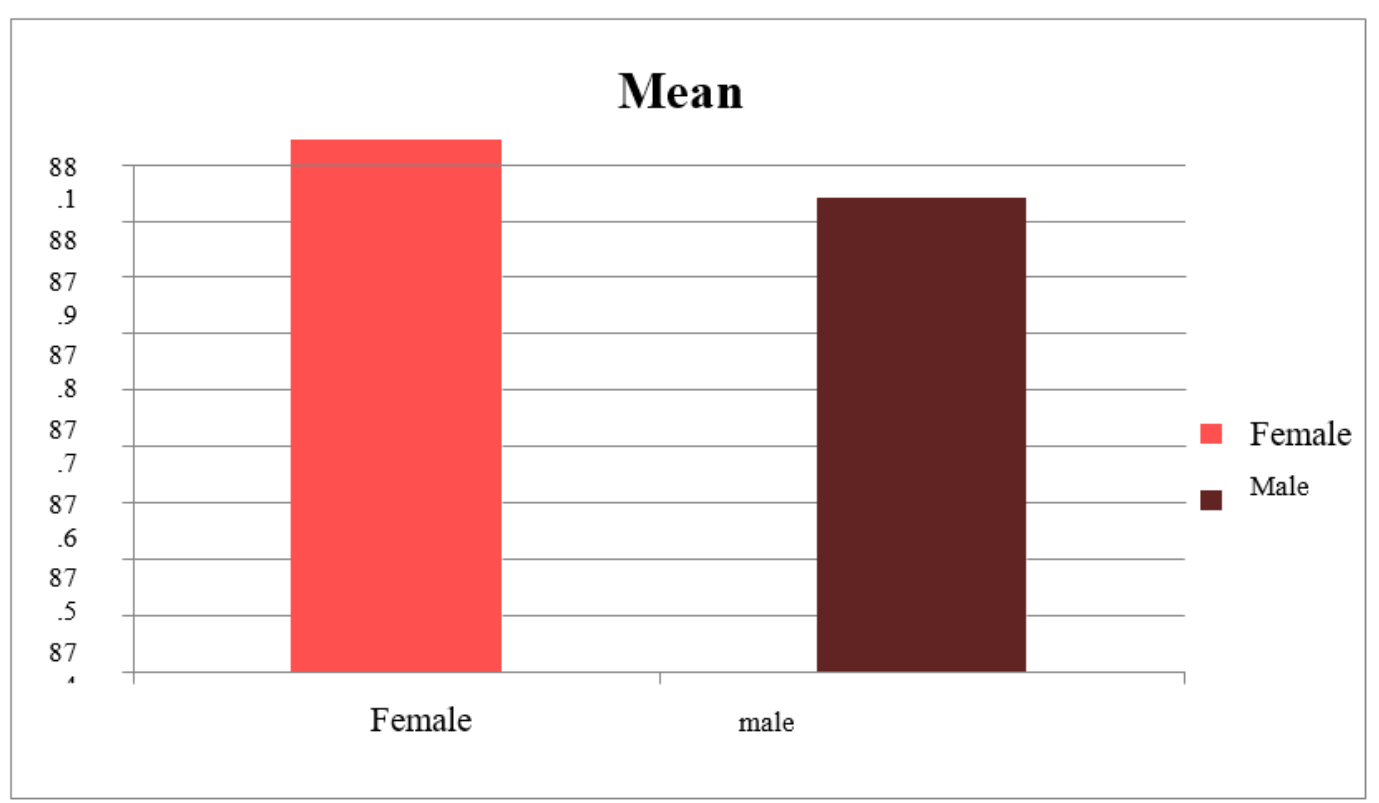

Fig. 3: Shows graphical representation of academic stresses mean scores of girls and boys enrolled in science stream.

Table 4 and Fig. 4 show dimension wise data of academic stress mean scores of female and male enrolled in science stream. It is clear from the (Table 4 and fig. 4) that female and male enrolled in science stream vary significantly on three dimensions out of four dimensions namely -Interpersonal relationship (D-2), academic (D3), and environment (D-4). It is quite clear that interpersonal relationship and environment causes more academic stress in male while academic causes more academic stress in female enrolled in science stream.

Table 4: Shows dimension wise academic stress mean scores of girls and boys enrolled in science stream.

\begin{tabular}{|c|c|c|c|c|c|}
\hline & & & & & Level of \\
\hline Dimensions & Groups & $\mathbf{M}$ & SD & t- value & significance \\
\hline & Female & 19.3 & 3.02 & & \multirow{3}{*}{ NS } \\
\hline \multirow[t]{2}{*}{ Physical } & & 7 & & \multirow{2}{*}{0.32957} & \\
\hline & Male & 19.1 & 2.25 & & \\
\hline
\end{tabular}




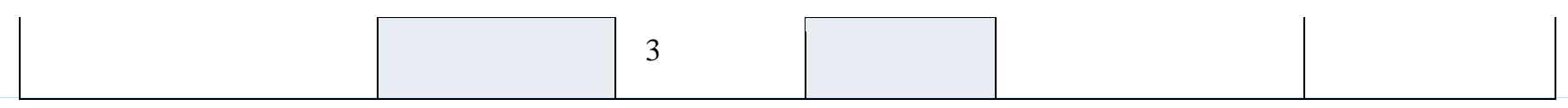

\begin{tabular}{|c|c|c|c|c|c|}
\hline \multirow{2}{*}{ Interpersonal skills } & Female & 16.1 & 2.40 & \multirow[t]{2}{*}{-2.45789} & \multirow{2}{*}{$\mathrm{S}^{* *}$} \\
\hline & Male & 17.93 & 3.30 & & \\
\hline \multirow[t]{2}{*}{ Academic } & Female & 18.33 & 3.39 & \multirow{2}{*}{1.39407} & \multirow{2}{*}{ NS } \\
\hline & Male & 17.3 & 2.70 & & \\
\hline \multirow{4}{*}{ Environment } & Female & 14.8 & 2.56 & \multirow{4}{*}{-1.96891} & \multirow{3}{*}{$S^{* *}$} \\
\hline & & 9 & & & \\
\hline & \multirow[t]{2}{*}{ Male } & 16.2 & \multirow[t]{2}{*}{2.36} & & \\
\hline & & 5 & & & \\
\hline
\end{tabular}

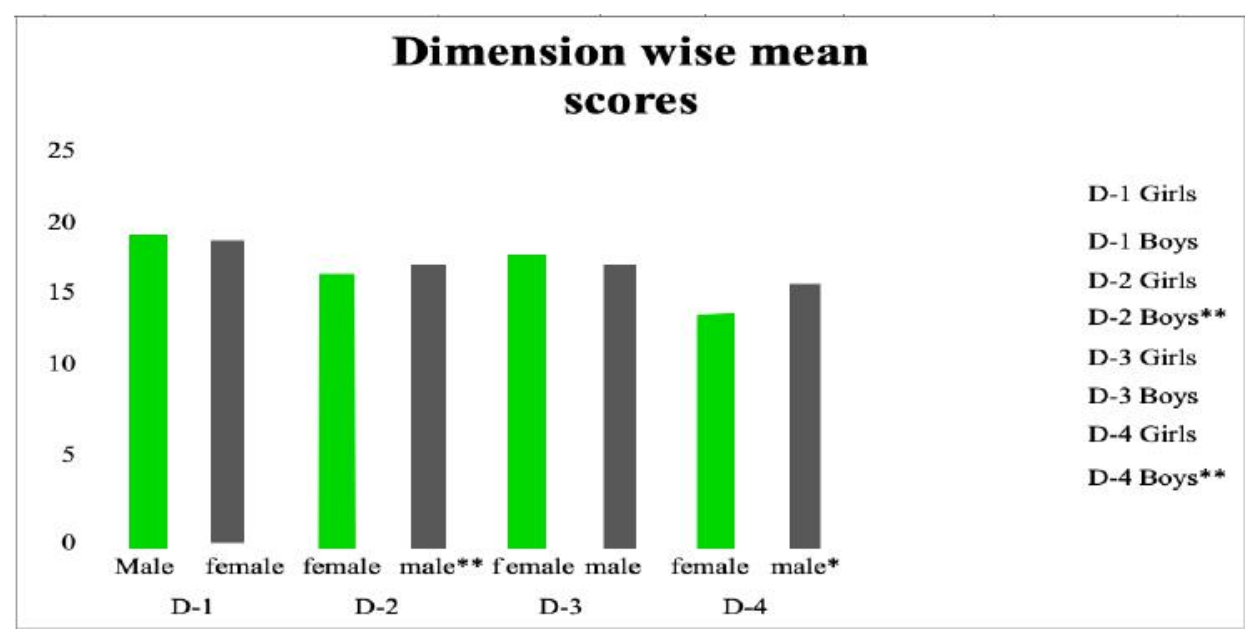

Fig. 4: Shows graphical representation dimension wise academic stress mean scores of students enrolled in science stream.

Table 5 and Fig. 5 show data on difference of academic stress among male and female enrolled in arts stream. The mean score of academic stress of boys enrolled in arts stream is 89.52 while that of the girls enrolled in arts stream is 78.2 . The obtained t-value $\left(2.8703^{* *}\right)$ is found to be significant as compared to the table value
(0.006531), so there is statistically significant difference exists between academic stress of boys and girls enrolled in arts stream at $\mathrm{p}=0.05$ level. The result revealed that male enrolled in arts stream were found academically more stressed as compared to female enrolled in arts stream hence hypothesis second was rejected. 
Table 5: Shows difference between academic stresses of girls and boys enrolled in arts stream.

\begin{tabular}{|c|c|c|c|c|l|}
\hline Group & N & Mean & SD & $\begin{array}{c}\text { 't' } \\
\text { value }\end{array}$ & \multicolumn{2}{|c|}{ Level of significance } \\
\cline { 1 - 4 } Male & 25 & 89.52 & 12.24 & 2.8703 & S** \\
\hline Female & 25 & 78.2 & 19.85 & \\
\hline
\end{tabular}

\section{Significant at $\mathbf{P}=\mathbf{0 . 0 5}$}

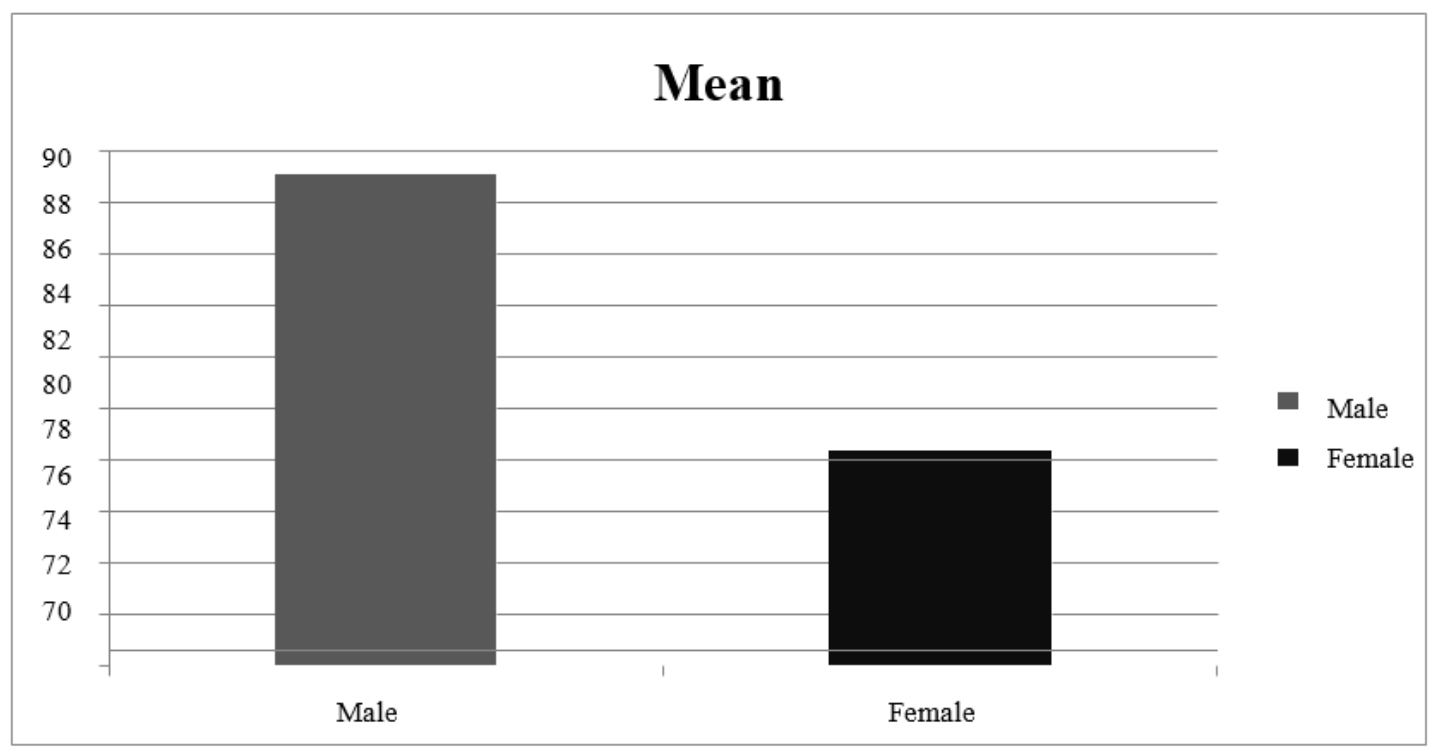

Fig. 5: Shows graphical representation of academic stresses mean scores of girls and boys enrolled in arts stream.

Table 6 and Fig. 6 show dimension wise data of academic stress mean scores of male and female enrolled in arts stream. It is clear from the (Table 6 and fig.6 that male and female enrolled in arts stream vary significantly on three dimensions out of four dimensions namely physical (D-1),

academic(D-3) " and environment(D-4)" and all three dimensions cause more academic stress in boys as compared to girls enrolled in arts stream.

Table 6: Shows dimension wise academic stress mean scores of girls and boys enrolled in arts stream.

\begin{tabular}{|c|c|c|c|c|c|}
\hline Dimensions & Groups & $\mathbf{M}$ & SD & t- value & $\begin{array}{c}\text { Level of } \\
\text { significance }\end{array}$ \\
\hline \multirow[t]{2}{*}{ Physical } & Boys & 19.86 & 2.82 & \multirow{2}{*}{3.72209} & \multirow[t]{2}{*}{$\mathrm{S} * *$} \\
\hline & Girls & 16.1 & 4.51 & & \\
\hline \multirow{2}{*}{$\begin{array}{l}\text { Interpersonal } \\
\text { relationship }\end{array}$} & Boys & 16.62 & 2.56 & \multirow[t]{2}{*}{-0.83285} & \multirow[t]{2}{*}{ NS } \\
\hline & Girls & 17.38 & 4.65 & & \\
\hline Academic & Boys & 17.98 & 3.88 & 22.9065 & $\mathrm{~S}^{* *}$ \\
\hline
\end{tabular}




\begin{tabular}{|l|c|c|c|c|c|c|}
\hline & Girls & 14.96 & 3.99 & & & \\
\hline \multirow{2}{*}{ Environment } & Boys & 15.16 & 2.10 & & 0.21143 & NS \\
\cline { 2 - 7 } & Girls & 14.86 & 4.60 & & & \\
\hline
\end{tabular}

\section{Dimension wise mean scores}

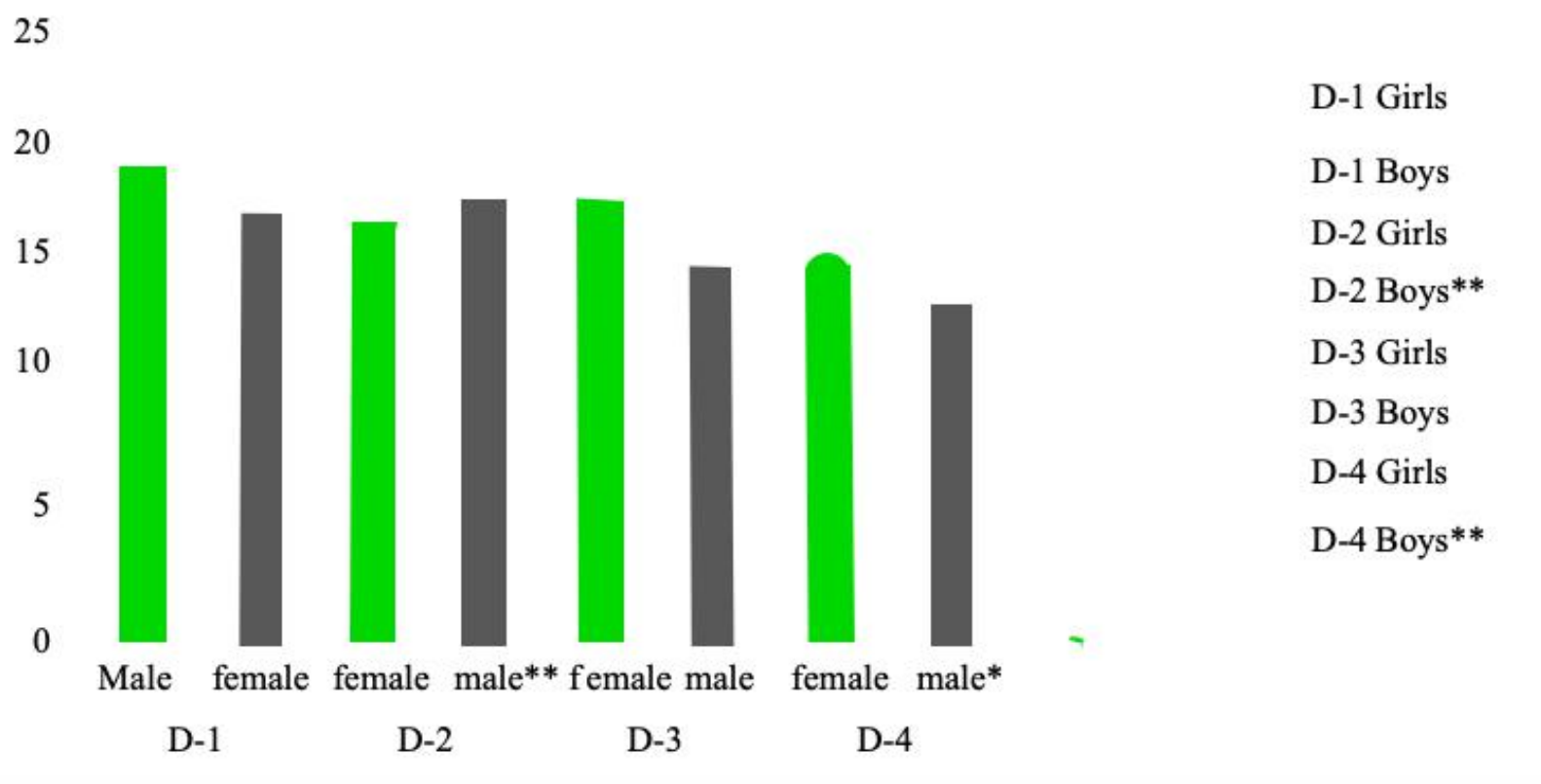

Fig. 6: Shows graphical representation dimension wise academic stress mean scores of students enrolled in arts stream.

\section{FINDINGS}

Major findings of the present study are-

1. When students enrolled in science and arts streams compared together, they differed significantly in their academic stress. Students enrolled in science stream were found academically more stressed as compared to students enrolled in arts stream. The dimensions 'Environment' causes more academic stress in students enrolled in science stream and 'Interpersonal relationship' causes more academic stress in students enrolled in arts stream.

2. When girls and boys enrolled in science stream compared together, they didn't vary significantly in their academic stress. However, the dimensions interpersonal relationship and environment causes more academic stress in male while academic causes more academic stress in female enrolled in science stream.

3. When male and female enrolled in arts stream com- pared together, they vary significantly in their academic stress. Male enrolled in art stream were found academically more stressed than female enrolled in arts stream. The dimensions physical (D-1), academic(D-3) and environment(D-4), and all the three dimensions cause more academic stress in boys as compared to girls enrolled in arts stream.

\section{CONCLUSION}

Consequences of the current investigation indicated that understudies took a crack at science may run over an assortment of stress prompting circumstances likephysical, relational relationship, scholarly and condition which may expand the pressure especially in scholastics. It was additionally discovered that male took a crack at expressions stream may go over an assortment of stress prompting circumstances in regards to their scholarly about their condition and physical that expands the degree of worry among them. It is, along these lines, recommended to create projects and systems to adapt up to the under- 
studies "stressors". It is additionally suggested that guardians ought to never force additional weight upon their youngsters and educators should be helpful.

\section{REFERENCES}

[1] Edward Samuel, S. Kalaivani (2017). Prime labeling for some vanessa related graphs. Indian journal of applied research 7(4) pp 136-145.

[2] Anand, N. and Devi, N. (2012): Academic stress in relation to self-efficacy and peer relations among college students. Indian Journal of Health and Wellbeing 3(3), 735-736.

[3] Arip, M.A. (2002). Student Stress Inventory (SSI). Tanjong Malim Preak, Malaysia.

[4] Baum, A. (1990): Stress, Intrusive Imagery, and Chronic Distress. Health Psychology 9(6), 653-675.

[5] Bandura, A., (1986), Social Foundation of Action and Thought: A Social Cognitive Theory, Englewood Cliffs; NJ: Prentice Hall.

[6] Bandura, A., (1997), Self-efficacy: the exercise of control, New York: W.H. Freeman and Company.

[7] Bataineh, M. Z. (2013): Academic Stress Among Undergraduate Students: The Case of Education Faculty at King Saud University. International Interdisciplinary Journal of Education 2(1), 82-88.

[8] Baviskar, P. M., Phalke, V.D. and Phalke, D. B. (2013): Depression, Anxiety and Stress: A comparative study in Arts, Commerce \& Science Junior College students in Rural Area of India. GRA - Global Research Analysis 2(11), 183-185.

[9] Brooks-Gunn J., Aber J. L., Duncan G. (1991) Children, Youth and Environments, 14 (2004). Neighborhood Poverty: Context and Consequences for Children, Volume 1. Russell Sage Foundation, New York.

[10] Chan, K. Y., Hung, E. C. S., Pin, H. Y., \& Ithnin, H. B. (1999). Stress among medical students in a medical college of South India/ Commentary. Education for Health, 12(1), 63.

[11] Cooper, G. L., Dewe, Ph. J., \& O’Driscoll, M. P. (2001). Organizational stress. A review and critique of theory, research and applications. London: Sage Publications, Inc.

[12] Crime in India National Crime Records Bureau. Retrieved from $\quad$ http://ncrb.nic.in/cii2008/figure\%20 at\%20a\%20glance.pdf.2014.

[13] Dhull, I., and Kumari, S. (2015): Academic Stress Among Adolescents in Relation to Gender. International Journal of Applied Research 1(11), 394-396.

[14] Dimitrov.G (2017). A study on the impact of Academic Stress among college students in India, Ideal Research. 2(4)

[15] Francis D. (1999) Nongenomic transmission across generations of maternal behaviour and stress responses. Science, 286, 1155.

[16] Franken, R.E. (1994). Human Motivation, 3rd ed. Belmont, CA: Brooks/Cole Publishing Company.

[17] Ghosh, S. M. (2016): Academic Stress Among Government and Private High School Students. The International Journal of Indian Psychology 3(2/8), 119-125.
[18] Kadapatti, G.M and Vijayalaxmi, A. (2011): Academic Stress and Coping Strategies among Preuniversity Students: a Comparative Study. Indian Journal of Health and Wellbeing 2(2), 510-512.

[19] Kaur, M. and Kaur, G. (2016): Academic Stress in Relation to Emotional Stability of Adolescent Students. International Journal in Management and Social Science 4(5), 35-41.

[20] Krishan Lal (2014). Academic stress among adolescent in relation to intelligence and demographic factors. American International Journal of Research in Humanities, Arts and Social Sciences, 5(1) pp. 123-129.

[21] Krishna Choudhury, Krishna Das (2018). A correlational study between parental expectations and level of stress among adolescents studying in selected High School of Kamrup (Rural) District, Original Research Article IP Journal of Paediatrics and Nursing Science, 1(3) pp 58-63.

[22] K. Jayasankara Reddy, Karishma Rajan Menon, AnjanaThattil (2018). Academic stress and its sources among university students. Biomed Pharmacol J, 11(1) pp 531537.

[23] Kumari, A. and Jain J. (2014): Examination Stress and Anxiety: A Study of College Students. Global Journal of Multidisciplinary Studies 4(1), 31-40.

[24] Lazarus, R. S., \& Cohen, J. P, (1999), “'Stress and emotion: A new synthesis", New York: Springer.

[25] Lazarus, R. S., \& Folkman, S. (1984), Stress, Appraisal and Coping, New York: Springer.

[26] Lee, M., \& Larson, R. (2000). The Korean 'examination hell': Long hours of studying, distress and Depression. Journal of Youth and Adolescence, 29, pp 249-271.

[27] Leka, Stavroula. (2003). "Work organization and stress: systematic problem approaches for employers, managers and trade union representatives, pp 8". World health organization: (Protecting worker's health series; no. 3). ISBN 92 41590475.

[28] Levine, S., \& Ursin, H., 1991. What is stress? In M. R. Brown, G. F. Koob, C. Rivier (Eds.), Stress: Neurobiology and Neuroendocrinology (pp. 3-21). New York: Marcel Dekker, Inc.

[29] Lumsden, D. P. (1981). Is the concept of "stress" of any use, anymore? In Contributions to Primary Prevention in Mental Health:Working Papers, ed. D. Randall. Toronto: Toronto Natl. Off. Can. Mental Health Assoc.

[30] Meijman, T. F., \& Mulder, G. (1998). Psychological aspects of workload. In P. J. D. Drenth \& H. Thierry (Eds.), Handbook of work and organizational psychology. Work psychology (pp. 5-33). Hove, England: Psychology Press. Vol. 2

[31] Prabu Suresh P (2015). A study on academic stress among higher secondary stress, International Journal of Humanities and Social Science Invention, 4(10), 63-68

[32] Rangaswamy, K., 1982, Tension headache in adolescents. Journal of Psychological Researchers, 26(2), 70-72.

[33] Saha D. Every hour one student commits suicide in India. Hindustan Times. Retrieved from.**(It is a article of newspaper, link is given below). https://archive.indiaspend.com/special-reports/a-studentcommits-suicide-every-hour-in-india-3-85917 
[34] Schwarzer, R. (Ed.). (1992). Self-efficacy: Thought control of action. Washington, DC: Hemisphere

[35] Seyle, H. (1976), Stress in Health and Disease, MA: Butterworth, Reading.

[36] Sharma, V. (2014): Effect of Gender and Stream on Depression among Adolescents. International Journal of Education and Psychological Research 3(2), 46-49.

[37] "Stress"(http://www.mentalhealthamerica.net/conditions/str ess).Mental Health America.2013-11-18.Retrieved 2018$10-01$

[38] Taylor, Shelley, E. (2015). "Health Psychology 9th Ed". (pp 113). McGraw-Hill Education. ISBN 978-0-07-7861810 .

[39] Tina and Annayat, R. (2014): Academic Anxiety of Adolescents in Relation to Their Vocational and Educational Interest. International Journal of Educational Research and Technology 5(3), 1-12.

[40] Ursin, H., Eriksen., H. R. (2003) Review:Thecognitive activation theory of stress. Psych neuroendocrinology, 29. Elsevir, 567-592.

[41] Verma, S. Sharma, D., \& Larson, R. W., 2002, School stress in India: Effects on time and daily emotions. International Journal of Behavioral Development, 26(6), 500-508.

[42] Vasile, C., Albu, G. (2011). Experimental Investigations on Professional Identity, VocationalPersonality Type and Stress Level in Adults. Procedia - Social and Behavioral Sciences, 30, 1801-1805.

[43] Wong, P. T., Wong, L. C., \& Scott, C. (2006). Beyond stress and coping: The positive psychology of transformation. In Handbook of multicultural perspectives on stress and coping (pp. 1-26). Springer US. 